\title{
THE IMPACT OF IN-HOUSE TRAINING ON THE DIVERSITY DIMENSIONS OF EMPLOYEદ PRODUCTIVITY IN THE SOUTH AFRICAN WORKPLACE
}

\author{
Gerhardus van Zyl* \\ University of Johannesburg
}

Received: May 2016

Accepted: December 2016

\begin{abstract}
The aim of this article is to determine the impact of in-house training (defined as any training provided by firms in the workplace) on employee productivity, employee remuneration and net employee productivity gains when diversity attributes of the workplace are taken into consideration. The manufacturing industry of Gauteng Province of South Africa is used as a case study. Fixed-effect panel data estimations were performed in order to determine the diversity-based employee productivity, remuneration and net productivity differentials of in-house training. The results accentuate the important positive productivity, remuneration and net productivity spill-over effects created by inhouse training opportunities. The outcomes of the study also confirm the importance of a workplace that is more gender diverse, racial diverse and in which skilled and older experienced employees are retained if the productivity spill-over effects generated by in-house training opportunities are to be enhanced.
\end{abstract}

Keywords

In-house trained employees, diversity dimensions, fixed-effect panel data estimations, employee productivity, employee remuneration, net productivity gains

*Prof $\mathbf{G}$ van Zyl is a professor in the Department of Economics and Econometrics, University of Johannesburg, South Africa. [hardusvz@uj.ac.za] 


\section{INTRODUCTION}

The aim of this article is to determine the impact of in-house training (defined as any training provided by firms in the workplace) on employee productivity, employee remuneration and net employee productivity gains when diversity attributes of the workplace are taken into consideration. The manufacturing industry of Gauteng Province of South Africa is used as a case study.

The article forms part of an extensive research project on different aspects of employee productivity in the South African workplace. This particular study covers both the employee productivity and real employee remuneration impacts of in-house training on various employee diversity dimensions. The diversity dimensions that are taken into consideration are differences in skill levels, gender differences, different age groups and the racial composition of the workforce. Literature on the employee productivity impacts of in-house training in developing countries is very limited, while published literature for developed economies in this regard generally indicates positive impacts of in-house training on both employee productivity and real wages (Konings \& Vanormelingen, 2010; Acemoglu \& Pischke, 1998; Black \& Lynch, 2001; Dearden, Reed \& Reenen, 2006; Moretti, 2004; Van Biesbroeck, 2010; Bauernschuster, Falck \& Heblick, 2009, Arumlampalam \& Booth, 2001, Gavrel \& Lebon, 2009). In order to expand the debate on employee productivity in South Africa it is deemed important to determine what the magnitude of the positive employee productivity and real employee remuneration impacts are if in-house training practices are enhanced. In the estimation process the study encompasses important diversity attributes, in-house training intensities, marginal efficiencies of in-house trained employees, inhouse trained employee remuneration costs and the net employee productivity gains for the firm.

\section{LITERATURE STUDY}

The majority of published research articles indicate the constant pressure to upgrade employee skill levels in the workplace in order to keep pace with rapid technological advancements and the contribution of in-house training practices fulfilling an integral part in this regard (Konings, et al., 2010; Acemoglu et al., 1998; Black et al, 2001; Dearden et al., 2006; Moretti, 2004; Van Biesbroeck, 2010 and Gavrel et al., 2009). These studies also conclude that in-house training practices have a positive impact on employee productivity levels, that the marginal employee productivity efficiencies of in-house trained employees is substantially higher when compared to employees who have not undergone any in-house training, that employee remuneration levels are enhanced by in-house training practices and that there are industry differences in the magnitude of the in-house training practices-employee productivity link.

Konings et al. (2010) specifically argue in favour of in-house training that is specific (not general) in nature due to the efficient nature of such training in terms of the enhancement of employee productivity effects and the spill-over effects that it creates in the workplace. Moretti (2004) is of the opinion that a lack of firm-based in-house training data is the single biggest reason for relatively limited research on the employee productivity effect of specific in-house training practices when compared to the vast literature on employee productivity effects of general training (such as more efficient education levels). The study by Ackerberg, Caves and Frazer (2015) concludes that the greater availability of firm-based data on in-house training practices creates very important benefits for research in this regard. These benefits are multiple applications of firm-based in-house training data sets, the elimination of aggregation biases and 
control for any endogeneity issues. Bauernschuster et al. (2009) conclude that firms' decisions to invest in in-house training are based purely on the real employee productivity benefits that may flow from in-house training.

The studies by Koning et al. (2010), Bauernschuster et al. (2009) and Gavrel et al. (2009) indicate that in nearly all of the cases the marginal employee productivity efficiencies generated by inhouse training practices are higher than real increases in employee remuneration levels that flow from in-house training. Net employee productivity benefits are thus created for firms that invest in in-house training practices. Acemoglu et al. (1998) further indicate a lower employee turnover as a result of effective in-house training practices.

The studies of Jones (2001), Hellerstein, Newmark and Troske (1999), Van Biesbroeck (2010), Konings et al. (2010) and Dearden et al. (2006) employ both production function and employee remuneration estimation models in order to compare the real employee remuneration levels with the real employee productivity levels that resulted from in-house training practices. These studies use a Hicks-neutral technical efficient Cobb-Douglas format in which value added, capital input and labour input are included. In order to differentiate between specific firm-based and general components and to cater for time-specific deviations (from an average employee productivity level) a natural logarithm format is used. Added advantages are that these models also cater for the amount of in-house training practices and the intensity thereof. The estimation models are also driven by the implicit assumptions that i) in-house trained and untrained employees are perfect substitutes, ii) that in-house trained employees have similar employee productivity gains, and iii) that in-house training is not treated as a binary variable. The basic premises of these particular assumptions are that the level of the marginal efficiencies of inhouse trained employees can be determined relative to untrained employees, the in-house trained productivity estimates are treated as average employee productivity impacts and employees differ only in the amount of in-house training that they receive. The training intensity estimation allows researchers to estimate average training costs and the determination of the spill-over effect on employee remuneration levels should the intensity of in-house training change. The real in-house training employee productivity gains are derived from the linear estimation of value added on the employee input, capital input and the share of in-house trained employees. A positive estimate of the share of in-house trained employees would indicate that the marginal efficiency levels of in-house trained employees are higher than the marginal efficiency levels of employees who have not undergone any form of in-house training.

The estimation models also consider the employee remuneration differentials between employees who have undergone in-house training and those employees who have not undergone any in-house training. The aim is to determine the impact of in-house training on employee remuneration levels. Basically, the relative employee remuneration benefit for in-house trained employees is the difference between the average remuneration levels of in-house trained employees and the untrained employees divided by the average employee remuneration level of untrained employees.

\section{RESEARCH DESIGN}

\subsection{Research approach and method}

The research design comprises the 
- identification of the various diversity dimensions to be included in the in-house trainingemployee productivity estimation model,

- specification of the adapted in-house training-employee productivity estimation model,

- compilation of firm-based data sets of in-house training, diversity dimensions and employee remuneration levels for the proxy firms in the manufacturing industry of Gauteng Province,

- estimation process and

- interpretation of the estimation results.

\subsection{Model specification}

The study employs an adapted simplified version of the Konings et al. (2010) model. In the adapted version of the estimation model employee diversity dimensions (gender, race, skill levels and different ages) are included. The adapted model is explained in the following few paragraphs.

$$
y_{i t}=\beta_{0}+\beta_{\text {Litgras }}+\beta_{\text {litgras } \emptyset_{t}} \frac{\text { Lt,itgras }}{\text { Litgras }}+\beta m_{\text {itgras }}+\beta_{k} K_{i t}+w_{i t}+\eta_{\text {itgras }}
$$

(where $y_{i t}=$ real sales for firm $\mathrm{i}$ in period $\mathrm{t} ; \beta_{0}=$ fixed component that is common to all the firms; $\beta_{\text {litgras }}=$ the quality of the employee aggregate for firm i for period $t$ and for each gender grouping, race grouping, age grouping and skills level; $\beta_{\text {Litgras }} \emptyset_{t}=$ the marginal productivity differential between in-house trained employees (per gender grouping, race grouping, age and skills groupings) and untrained employees, where $\frac{\text { Lt, itgras }}{\text { Litgras }}$ is the ratio of trained employees per gender grouping, race grouping, age and skills groupings for firm $\mathrm{i}$ in period $\mathrm{t} ; \beta \mathrm{m}_{\text {itgras }}=$ the production material input for firm $\mathrm{t}$ in period i per gender grouping, race grouping, age and skills groupings; $\beta_{k} K_{i t}=$ capital outlay for firm $i$ in period $t ; w_{i t}=$ unobserved employee productivity effects such as employee remuneration disputes, technological advancement and production run stoppages for firm $\mathrm{i}$ in period $\mathrm{t} ; \eta_{\text {itgras }}=$ mean zero error term)

The Konings et al. (2010) model explicitly caters for the timing of capital accumulation in order to circumvent correlation of the capital outlay input and employee productivity in the same year $(t)$. The decision to investment in production capital outlay is taken in the previous period $(t-1)$ and the aim is to identify the capital outlay coefficient in the estimation. The model is also based on the assumption that a firm's expectations of future employee productivity (per diversity dimension) depend in the main on current employee productivity levels. The model clearly distinguishes between the production material input and the capital outlay input based on the assumption that the production material input is chosen after the employee and in-house training inputs. This is especially true for rigid labour markets such as the South African labour market. The demand for the production material input is a function of the production capital outlay, employee productivity and in-house training. It is also important to note that the production material input is based on a monotonic conditionality between employee productivity levels and the efficient usage of the production material input (the higher the employee productivity levels the higher the efficient usage of the production material input). Employee productivity is the only unobservable element in $m_{\text {itgras }}$ based on the assumption that all other input prices are treated as constant. The production material input $\left(m_{\text {itgras }}\right)$ is inverted to obtain an expression for employee productivity, as the production material input is directly dependent on the quality of the employee input (per gender grouping, race grouping, age and skills groupings) of firm i in period $t$, the production capital outlay of firm $i$ in period $t$ and the fraction of in-house trained employees 
for firm $\mathrm{i}$ in period $\mathrm{t}$ (per gender grouping, race grouping, age and skills groupings). The production material input function $\left(\mathrm{m}_{\text {itgras }}\right)$ can be presented as $\mathrm{f}_{\mathrm{t}}^{-1}\left(\mathrm{~m}_{\text {itgras }}, \mathrm{L}_{\text {itgras }}, \frac{\text { Lt,itgras }}{\text { Litgras }}, \mathrm{K}_{\mathrm{it}}\right)$.

It is also deemed important to determine the employee productivity differential between inhouse trained employees and non in-house trained employees. The coefficient on the share of inhouse trained employees is divided by the labour coefficient $\left(\emptyset_{\mathrm{t}} \frac{\text { Lt,itgras }}{\text { Litgras }}\right)$.

In order to compare the employee productivity benefits of in-house trained employees with the remuneration benefits of in-house trained employees, employee remuneration estimates are derived.

$$
\text { rem }=\operatorname{rem}_{u}+\lambda_{\mathrm{T}} \frac{L t}{L}+X \gamma+\varepsilon
$$

(where rem = employee remuneration, rem $_{u}=$ average remuneration, $\lambda_{T} \frac{L t}{L}=$ relative remuneration premium for in-house trained employees, $X \gamma=$ diversity dimensions of employee remuneration)

In the Konings et al. (2010) model the intensity of the employee productivity in-house training effect is defined as $\beta_{T}=$ average training intensity estimate/labour estimate and the aim of estimating $\beta_{T}$ is to determine the impact of the in-house training intensity on employee productivity and to compare the calculated coefficients to the employee remuneration in-house training intensity estimates. The estimations are controlling for possible endogeneity of in-house training in both the employee productivity and employee remuneration equations.

The study employs fixed-effect panel data estimations for the in-house trained employee productivity-gender dimension, the in-house trained employee productivity-race dimension, the in-house trained-age dimension, the in-house trained employee productivity-skills dimension, the in-house trained employee remuneration-gender dimension, the in-house trained employee remuneration-race dimension, the in-house trained employee remuneration-skills dimension and the in-house trained employee remuneration-age dimension. In order to facilitate comparisons with other research and studies that deal with the diversity dimensions of employee productivity the following gender, race, age and skills level categories are used in this study:

- For gender attributes two categories are used, namely a gender distribution of less than $25 \%$ female participation and a gender distribution of more than $25 \%$ female participation in the workplace (Van Zyl, 2013 and Van Zyl, 2014).

- For race attributes a category in which one specific race group has more than a $60 \%$ share and a category where no particular race group has more than a $60 \%$ share in the workplace are used (Van Zyl, 2013 and Van Zyl, 2014).

- In terms of the age attribute three groups are used, namely employees 35 years of age and younger, between 35 and 55 years of age and 55 years of age and older (Van Zyl, 2013 and Van Zyl, 2014).

- For the skills attribute the International Standard Classification of 0ccupations (ISCO-88) is used in order to distinguish between more skilled occupations (Category A) and less skilled occupations (Category B) in the workplace (Van Zyl, 2013).

Fixed-effect panel data estimations are done for each of the in-house trained employeesdiversity attributes. 


\subsection{Data collection process}

In order to capture the employee productivity impacts of the different in-house trained-diversity attribute dimensions, the manufacturing industry of Gauteng Province is used as a case study, given the importance of the manufacturing industry in the gross geographical product (GGP) of Gauteng Province and also given the availability of firm-based data.

Contact information was supplied by the Manufacturing Sector Education and Training Authority (MERSETA), Department of Labour and the Chamber of Business. Data was supplied by the individual firm in the sample group. Statistical validation requires a representative sub-sector spread of firms in the manufacturing industry of Gauteng Province. The sample response of 107 firms, which covers a variety of sub-sectors in the Gauteng manufacturing industry, is confirmed to be statistically significant.

The sample period was for the calendar years 2010-2013. For each firm in the sample group data was collected on the number of employees, the number of employees per gender group, race, age and skills groupings, average firm real sales turnover, average employee remuneration per gender, race, age and skills level groupings, the proportion of in-house trained employees per gender, race, age and skills groupings, the average training cost per employee per gender, race, age and skills level groupings, time spent on in-house training per gender, race, age and skills groupings, the size of the production capital outlay and the size of the production material outlay. A summary of the sample statistics is provided in Appendix 1 and the log format of the data set is provided in Appendix 2.

It should be noted that in-house training encompasses the total number of in-house training opportunities. Individual employees could have attended more than one in-house training opportunity. The second column of Appendix 1 indicates the average number of employees for the sample of firms who have undergone some form of in-house training (per diversity category). There are individual employees who have not undergone any form of in-house training. The third column of Appendix 1 indicates the average number of employees for the sample of firms (for all the diversity categories) who have not undergone any form of in-house training.

For the sample of firms in the study the following can be deduced from Appendix 1:

- The average number of employees is 97 employees. An average number of 65.7 employees have undergone some form of in-house training while an average of 24.9 employees have not undergone any form of in-house training. The majority of employees on average have undergone some form of in-house training.

- An average number of 33 employees were employed in workplaces where the female participation rate was higher than $25 \%$. For this category of female representation an average of 19.5 employees have received some form of in-house training while an average of 8.6 employees have received no in-house training. In terms of female participation of less than $25 \%$ representation in the workplace an average of 64 employees were employed. An average of 34.2 employees have received some form of in-house training while an average of 17.9 employees have received no form of in-house training. It is clear that for workplaces where female representation was less than $25 \%$, employment levels on average were nearly double that of employment levels for workplaces in which female representation was more than $25 \%$. On average, in-house training employee levels were much higher for workplaces where female participation levels were less than $25 \%$. 
- For a workplace in which one race group has a more than $60 \%$ representation of the workforce an average of 63 employees were employed, while for a workplace employee structure in which no individual race group has a greater than a $60 \%$ representation an average of 27 employees were employed. For a greater than $60 \%$ representation of one race group an average of 29.5 employees have received some form of in-house training, while an average of 14.2 employees have received no form of in-house training. For the less than $60 \%$ representation of one race group category an average of 14.3 employees have received some form of in-house training, while an average of 8.3 employees have received no form of inhouse training.

- In terms of the different age groups an average number of 29 employees in the 35 years and younger bracket, 46 employees in the 35-55 year bracket and 22 employees in the 55 and older age bracket are employed per firm in the sample of firms. For the sample of firms an average of 22.4 employees in the 35 years and younger age bracket, 35.8 employees in the $35-55$ age bracket and 19.7 employees in the 55 years and older age bracket have undergone some form of in-house training. For the sample of firms an average of 15.4 employees in the 35 years and younger age bracket, 16.7 employees in the 35-55 age bracket and 3.6 employees in the 55 years and older age bracket have undergone no form of in-house training. In terms of skill levels, an average of 33 employees are classified as category $A$ employees and 64 employees per firm are classified as category B employees (for the sample of firms). For category A employees an average of 29.2 employees have received some form of in-house training, while an average of 9.4 employees have received no form of in-house training. For category A employees on average 9.4 employees per firm have received no form of in-house training while an average of 17.5 category $B$ employees per firm have received no formal in-house training.

- The average real sales turnover for the sample of firms was R17 052000 . Average real sales turnover attributed to in-house trained employees was R13 403000 and for employees who have received no in-house training the average sales turnover was R4 283000.

- The average employee remuneration for the sample of firms was R85 400. Employees who have undergone some form of in-house training received an average remuneration of Rl15 100, whereas employees who have received no form of in-house training received an average remuneration of R38 400 .

- Average employee productivity for the sample of firms is calculated as the average real sales turnover divided by the average number of employees. For the sample of firms the average employee productivity is R175 790 and for employees who have undergone some form of inhouse training average employee productivity is R204 000 .

- For the sample of firms the average capital outlay is R19 063000 , the average capital/employee ratio is R196 520, the average material output is R2 720000 , the average material/employee ratio is $R 28040$, the portion of in-house trained employee opportunities is 0.65 , the average cost of in-house trained employees is Rl 423 and the average hours of in-house training per employee is 18 hours.

In order to determine the magnitude of in-house training of the dataset (when compared to non in-house training) log regressions are done for each of the key variables (including the subdiversity components) on a dummy variable that is equal to 1 when in-house training is provided and 0 otherwise. The coefficients of the in-house training dummy are then interpreted as either absolute size differences (average number of employees and real sales added) or a percentage 
difference (employee remuneration cost, employee productivity and the capital/employee ratio) (Konings et al., 2010).

From Appendix 2 the following can be deduced:

- A firm that offers in-house training is typically about three times the size of non in-house training firms.

- Employee remuneration is $26 \%$ higher, employee productivity is $33 \%$ higher and the capital/employee ratio is $22 \%$ higher for firms that offer in-house training.

\section{ESTIMATION RESULTS}

The panel data estimates for the impact of in-house training on employee productivity, employee remuneration, in-house training intensity and the net productivity benefits for the sample of firms (for the different diversity dimensions) are presented in this section.

TABLE 1: Panel data estimates for the impact of in-house training on employee productivity (for the different diversity dimensions)

\section{Full sample \\ estimates \\ (excluding material \\ cost)

Full sample
estimates (including
material cost)

Full sample

estimates (controlling for endogeneity of

inputs)

\begin{tabular}{|c|c|c|c|}
\hline \multicolumn{4}{|l|}{ Labour: } \\
\hline Total & 0.913 & 0.864 & 0.814 \\
\hline $\begin{array}{l}\text { Less than } 25 \% \text { female } \\
\text { presentation }\end{array}$ & 0.902 & 0.812 & 0.758 \\
\hline $\begin{array}{l}\text { More than } 25 \% \text { female } \\
\text { presentation }\end{array}$ & 0.970 & 0.902 & 0.834 \\
\hline $\begin{array}{l}\text { More than } 60 \% \text { single race } \\
\text { presentation }\end{array}$ & 0.754 & 0.711 & 0.671 \\
\hline $\begin{array}{l}\text { Less than } 60 \% \text { single race } \\
\text { presentation }\end{array}$ & 0.808 & 0.724 & 0.693 \\
\hline Category A employees & 0.974 & 0.910 & 0.879 \\
\hline Category B employees & 0.825 & 0.723 & 0.650 \\
\hline Age 35 years and less & 0.651 & 0.591 & 0.561 \\
\hline $\begin{array}{l}\text { Age between } 35 \text { and } 55 \\
\text { years }\end{array}$ & 0.756 & 0.712 & 0.591 \\
\hline Age 55 years and older & 0.711 & 0.658 & 0.581 \\
\hline Captial & 0.241 & 0.215 & 0.192 \\
\hline
\end{tabular}




\begin{tabular}{|c|c|c|c|}
\hline & $\begin{array}{c}\text { Full sample } \\
\text { estimates } \\
\text { (excluding material } \\
\text { cost) }\end{array}$ & $\begin{array}{c}\text { Full sample } \\
\text { estimates (including } \\
\text { material cost) }\end{array}$ & $\begin{array}{c}\text { Full sample } \\
\text { estimates } \\
\text { (controlling for } \\
\text { endogeneity of } \\
\text { inputs) }\end{array}$ \\
\hline \multicolumn{4}{|l|}{ In-house training: } \\
\hline Total & 0.571 & 0.504 & 0.482 \\
\hline $\begin{array}{l}\text { Less than } 25 \% \text { female } \\
\text { presentation }\end{array}$ & 0.511 & 0.484 & 0.431 \\
\hline $\begin{array}{l}\text { More than } 25 \% \text { female } \\
\text { presentation }\end{array}$ & 0.668 & 0.524 & 0.514 \\
\hline $\begin{array}{l}\text { More than } 60 \% \text { single race } \\
\text { presentation }\end{array}$ & 0.473 & 0.413 & 0.375 \\
\hline $\begin{array}{l}\text { Less than } 60 \% \text { single race } \\
\text { presentation }\end{array}$ & 0.513 & 0.461 & 0.399 \\
\hline Category A employees & 0.643 & 0.543 & 0.509 \\
\hline Category B employees & 0.462 & 0.418 & 0.368 \\
\hline Age 35 years and younger & 0.477 & 0.425 & 0.386 \\
\hline $\begin{array}{l}\text { Age between } 35 \text { and } 55 \\
\text { years }\end{array}$ & 0.539 & 0.471 & 0.426 \\
\hline Age 55 years and older & 0.501 & 0.437 & 0.413 \\
\hline
\end{tabular}

Source: Author's analysis

*The estimates are significant at a $5 \%$ confidence level

All the panel data estimates are positive, thus indicating a positive relationship between in-house trained employees and employee productivity. Employee productivity is represented by the positive impact of in-house training opportunities on real sales. The panel data estimates become smaller when material costs are included in the estimations and even smaller when the estimations are controlled for endogeneity of inputs. The reason why the estimations are controlled for the endogeneity of inputs is the observation that larger firms are more likely to provide in-house training opportunities for employees. The effect is that the positive relationship between in-house training and employee productivity can result in an upward bias of the in-house training coefficients. The estimates are expressed as the impact of a $10 \%$ increase in the number of in-house trainined employees on real sales. The discussion of the panel data estimates will focus only on the last column of TABLE I (panel data estimates that controls for endogeneity of inputs), and the following can be deduced in terms of the positive impact of in-house training on real sales:

- A $10 \%$ increase in in-house training opportunities has a $4.82 \%$ positive impact on real sales.

- In terms of the gender dimension the positive impact on real sales is greater when the workplace is more gender diverse ( $5.14 \%$ versus $4.31 \%$ when in-house trained employees are increased by $10 \%)$. 
- A more racially diverse workplace has a stronger impact on employee productivity when inhouse training opportunities are increased by $10 \%$ (3.99\% versus $3.75 \%$ increase in real sales).

- The employee productivity impacts of in-house training for the higher skilled employee segment are more profound when compared to the less skilled employee segment $(5.09 \%$ versus $3.68 \%$ increase in real sales).

- The greatest employee productivity benefit generated by a $10 \%$ increase in in-house training opportunities is for the $35-55$ years of age grouping of employees, followed by the 55 years and older grouping $(4.26 \%$ versus $4.13 \%)$.

In order to determine the employee productivity differential between in-house trained employees and non in-house trained employees the marginal efficiency of each diversity segment is calculated. The employee marginal efficiency of in-house training opportunities is calculated as: $\frac{\text { In-house training estimate }}{\text { Labour coefficient }} \times \%$. The employee marginal efficiencies for the different diversity dimensions are listed in TABLE 2.

\section{TABLE 2: Marginal efficiency differential for in-house trained employees}

\begin{tabular}{lc}
\hline \multicolumn{1}{c}{ Diversity dimensions } & Marginal efficiency differential (\%) \\
\hline Total & 59.2 \\
Less than 25\% female presentation & 56.8 \\
More than 25\% female presentation & 61.6 \\
More than 60\% single race presentation & 55.9 \\
Less than $60 \%$ single race presentation & 57.6 \\
Category A employees & 57.9 \\
Category B employees & 56.6 \\
Age 35 years and younger & 68.8 \\
Age between 35 and 55 years & 72.1 \\
Age 55 years and older & 71.1 \\
\hline
\end{tabular}

Source: Author's analysis

The positive differentials between in-house trained employees and non in-house trained employees (for all the diversity dimensions) are in excess of $50 \%$. For the sample of firms the total employee productivity differential (marginal efficiency) for in-house trained employees is $59.2 \%$. The following in-house trained employee marginal efficiency differential observations for the different diversity dimensions can be deduced from TABLE 2 .

- The same diversity employee productivity patterns of in-house trained employees are indicated when TABLE 2 is compared to TABLE 1 .

- In terms of the gender dimension a more diverse workplace creates a greater employee marginal efficiency differential (61.6\% versus $56.8 \%$ ).

- A more race diverse workplace greates higher employee marginal efficiency differentials ( $57.6 \%$ versus $55.9 \%$ ). 
- Higher skilled employees create a higher employee marginal efficiency differential (57.9\% versus $56.6 \%$ ).

- The greatest employee marginal efficiency differential is created by the 35-55 year age grouping followed by the 55 year and older grouping.

TABLE 3 represents the panel data estimates for the impact of in-house training on employee remuneration. The aim of the estimates is to determine the remuneration differential of employees who have undergone some form of in-house training. The estimates are interpreted as percentage changes.

TABLE 3: Panel data estimates for the employee remuneration impacts of in-house training opportunities (for the different diversity dimensions)

\begin{tabular}{|c|c|c|c|}
\hline & $\begin{array}{l}\text { Full sample estimates } \\
\text { (log remuneration } \\
\text { regressed on share of } \\
\text { in-house trained } \\
\text { employees) }\end{array}$ & $\begin{array}{l}\text { Full sample estimates } \\
\text { (log remuneration } \\
\text { controlled for the } \\
\text { endogeneity of } \\
\text { inputs) }\end{array}$ & $\begin{array}{l}\text { Full sample estimates } \\
\text { (log remuneration, } \\
\text { capital/labour ratio } \\
\text { \& total factor } \\
\text { productivity included } \\
\text { as control variable) }\end{array}$ \\
\hline Total & 0.524 & 0.347 & 0.284 \\
\hline $\begin{array}{l}\text { Less than } 25 \% \text { female } \\
\text { presentation }\end{array}$ & 0.501 & 0.308 & 0.264 \\
\hline $\begin{array}{l}\text { More than } 25 \% \text { female } \\
\text { presentation }\end{array}$ & 0.608 & 0.389 & 0.298 \\
\hline $\begin{array}{l}\text { More than } 60 \% \text { single } \\
\text { race presentation }\end{array}$ & 0.576 & 0.432 & 0.212 \\
\hline $\begin{array}{l}\text { Less than } 60 \% \text { single } \\
\text { race presentation }\end{array}$ & 0.599 & 0.451 & 0.232 \\
\hline Category A employees & 0.534 & 0.352 & 0.217 \\
\hline Category B employees & 0.502 & 0.320 & 0.117 \\
\hline $\begin{array}{l}\text { Age } 35 \text { years and } \\
\text { younger }\end{array}$ & 0.429 & 0.301 & 0.134 \\
\hline $\begin{array}{l}\text { Age between } 35 \text { and } 55 \\
\text { years }\end{array}$ & 0.539 & 0.386 & 0.224 \\
\hline Age 55 years and older & 0.492 & 0.362 & 0.193 \\
\hline
\end{tabular}

Source: Author's analysis

*The estimates are significant at a $5 \%$ confidence level

For the sample of firms all the employee remuneration estimates are positive, indicating that employees who have undergone some form of in-house training are receiving remuneration levels that are higher than for those employees who have not undergone any form of in-house training. The last column of TABLE 3 indicates that for the sample of firms the remuneration levels of employees who have undergone some form of in-house training is $28.4 \%$ higher than the remuneration levels of employees who have not undergone any form of in-house training. In terms 
of all the diversity dimensions, the employee remuneration estimates indicate that the positive employee remuneration differentials are greater for a more diverse gender composition, a more race diverse workplace, higher skilled employees and for the $35-55$ year age grouping. The positive employee remuneration differentials of lower skilled and the younger age grouping are the lowest for the diversity dimensions of the sample group.

Net employee productivity gains for the sample of firms are possible only if the employee remuneration differentials are less than the employee productivity differentials. The last column of TABLE 2 (marginal efficiency differentials (\%)) is compared with the last column of TABLE 3 (\% differential of employee remuneration differential). It is clear that for all the diversity dimensions the marginal efficiency differentials are greater than the employee remuneration differentials. It can thus be concluded that in-house trained employees create positive net employee productivity benefits for the sample of firms.

It is important for the purposes of this particular study to compare the in-house training intensities of employee productivity and employee remuneration levels. The in-house training variable is expressed as the average training hours per employee. The aim is to determine the impact of the in-house training intensity on employee productivity and employee remuneration levels respectively. The average in-house training intensity estimates are presented in TABLE 4.

TABLE 4: In-house training intensity estimates (for the various diversity dimensions)

\begin{tabular}{lccc}
\hline & $\begin{array}{c}\text { Employee } \\
\text { productivity }\end{array}$ & $\beta T$ & $\begin{array}{c}\text { Employee } \\
\text { remuneration }\end{array}$ \\
\hline Capital outlay & 0.104 & \\
Labour & 0.829 & \\
Average in-house training intensity: & & 0.0077 & 0.0048 \\
Total & 0.0064 & 0.0111 & 0.0064 \\
Less than 25\% female presentation & 0.0092 & 0.0060 & 0.0040 \\
More than 25\% female presentation & 0.0050 & 0.0055 & 0.0038 \\
More than 60\% single race presentation & 0.0046 & 0.0062 & 0.0043 \\
Less than 60\% single race presentation & 0.0051 & 0.0094 & 0.0062 \\
Category A employees & 0.0078 & 0.0058 & 0.0038 \\
\hline Category B employees & 0.0048 & 0.0042 & 0.0027 \\
Age 35 years and younger & 0.0035 & 0.0057 & 0.0034 \\
\hline Age between 35 and 55 years & 0.0047 & 0.0054 & 0.0032 \\
\hline Age 55 years and older & 0.0045 & & \\
\hline
\end{tabular}

Source: Author's analysis

*The estimates are significant at a $5 \%$ confidence level

For all the diversity dimensions of the sample of firms the employee productivity intensities $\left(\beta_{T}\right)$ are greater than the employee remuneration intensities. This is a further confirmation of the 
existence of net employee productivity gains for the sample of firms due to in-house training opportunities.

\section{CONCLUSION}

The aim of the article was to determine the impact of in-house training (defined as any training provided by firms in the workplace) on employee productivity, employee remuneration and net employee productivity gains when diversity attributes of the workplace are taken into consideration.

Three aspects of the diversity dimensions of the in-house training-employee productivity relationship were estimated, namely the productivity differentials of in-house trained employees, the differentials of in-house trained employee remuneration levels and the net productivity gains for the sample of firms. The results of this particular study accentuate the important positive spill-over effects generated by in-house trained employees such as higher employee productivity levels, higher employee remuneration levels and net productivity gains for the sample of firms. In terms of the diversity dimensions, the results of the study confirm the importance of a more gender diverse workplace, a more racially diverse workplace, a more skilled workforce and the retaining of older more experienced employees if the net productivity benefits of in-house training are to be enhanced.

A possible further area of research is a comparable diversity-based multiple industry and geographical analysis of the in-house training-employee productivity relationship.

\section{LIST OF REFERENCES}

Acemoglu, D. \& Pischke, JS. (1998). Why do firms train? Theory and evidence. Quarterly Journal of Economics, 113(1), pp. 79-119.

Ackerberg, D., Caves, K. \& Frazer, G. (2015). Identification properties of recent production function estimators. Econometrica, 83(6), pp. 2411-2451.

Arumlampalam, W. \& Booth, A. (2001). Learning and earning: Do multiple training events pay? A decade of evidence from a cohort of young British men. $\varepsilon$ conomica, 68(271), pp. 379-400.

Bauernschuster, S., Falck, 0. \& Heblick, S. (2009). Training and innovation. Journal of Human Capital, $3(4)$, pp. 323-353.

Black, SE. \& Lynch, LM. (2001). How to compete: The impact of workplace practices and information technology on productivity. The review of economics and statistics, 83(3), pp. 434-445.

Dearden, L., Reed, H. \& Reenen, J.V. (2006). The impact of training on productivity and wages:

Evidence from British panel data. Oxford Bulletin of Economics and Statistics 68(4), pp. 397-421.

Gavrel, F. \& Lebon, I. (2009). Minimum wage, unemployment benefits and labour market efficiency. Louvain Economic Review, 74(1). pp. 53-75.

Hellerstein, J.K., Neuwmark, D. \& Troske, K.R. (1999). Wages, productivity and worker characteristics: Evidence from plant level production functions and wage equations. Journal of Labor Economics, 17(3). pp. 409-446. 
Jones, P. (2001). Are educated workers really more productive? Journal of Development Economics, 64(1). pp. 57-79.

Konings, J. \& Vanormelingen, S. (2010). The impact of training on productivity and wages: Firm level evidence, IZA DP, No. 4731. pp. 1-53

Moretti, $\varepsilon$. (2004). Workers education, spillovers and productivity: Evidence from plant-level production functions. American Economic Review, 94(3). pp. 656-690.

Van Biesebroeck, J. (2010). Wages equal productivity. Fact or Fiction?: Evidence from Sub Saharan Africa. World Development, 39(8). pp. 1333-1346.

Van Zyl, G. (2013). The relative labour productivity contribution of different age-skill categories for a developing economy: The Gauteng province of South Africa as a case study. The South African Journal of Human Resource Management, 11(1), pp. 1-8.

Van Zyl, G. (2014). Labour productivity and employee diversity in the South African workplace. Journal of Economic \& Financial Sciences, 7(2), pp. 451-466. 


\section{APPENDIX 1: SUMMARY STATISTICS}

\begin{tabular}{|c|c|c|c|}
\hline & Total & $\begin{array}{l}\text { In-house } \\
\text { training }\end{array}$ & $\begin{array}{l}\text { No in-house } \\
\text { training }\end{array}$ \\
\hline Average number of employees & 97 & 65.7 & 24.9 \\
\hline $\begin{array}{l}\text { Gender distribution of a more than } 25 \% \text { female } \\
\text { employee participation rate }\end{array}$ & 33 & 19.5 & 8.6 \\
\hline $\begin{array}{l}\text { Gender distribution of a less than } 25 \% \text { female } \\
\text { employee participation rate }\end{array}$ & 64 & 34.2 & 17.9 \\
\hline $\begin{array}{l}\text { Average number of specific race group greater } \\
\text { than } 60 \% \text { representation }\end{array}$ & 63 & 29.5 & 14.2 \\
\hline $\begin{array}{l}\text { Average number of specific race group less } \\
\text { than } 60 \% \text { representation }\end{array}$ & 27 & 14.3 & 8.3 \\
\hline Average number of age 35 and younger & 29 & 22.4 & 15.4 \\
\hline $\begin{array}{l}\text { Average number of age between } 35 \text { and } 55 \\
\text { years of age }\end{array}$ & 46 & 35.8 & 16.7 \\
\hline Average number of 55 years and older & 22 & 19.7 & 3.6 \\
\hline Average category A employees & 33 & 29.2 & 9.4 \\
\hline Average category B employees & 64 & 34.1 & 17.5 \\
\hline Average firm sales turnover $(x \mathrm{R} 1000)$ & 17052 & 13403 & 4283 \\
\hline Average employee remuneration ( $x \mathrm{R} 1000$ ) & 85.4 & 115.1 & 38.4 \\
\hline Average employee productivity (x Rl 000$)$ & 175.79 & 204 & 143 \\
\hline Average production capital outlay (x Rl 000) & 19063 & & \\
\hline Average capital/employee ratio (x Rl 000) & 196.52 & & \\
\hline Average production material outlay (x Rl 000$)$ & 2720 & & \\
\hline Average material/employee ratio (x R1 000) & 28.04 & & \\
\hline Portion of in-house trained employees & & 0.65 & \\
\hline Average cost of in-house training per employee & & $\mathrm{R} 1423$ & \\
\hline $\begin{array}{l}\text { Average hours of in-house training per } \\
\text { employee }\end{array}$ & & 18 hours & \\
\hline
\end{tabular}

Source: Author's analysis 


\section{APPENDIX 2: THE LOG REGRESSION COEFFICIENTS OF THE DIVERSITY ATTRIBUTES OF IN-HOUSE TRAINING}

\begin{tabular}{|c|c|}
\hline & $\begin{array}{c}\text { In-house training log } \\
\text { coefficients }\end{array}$ \\
\hline \multicolumn{2}{|l|}{ Average number of employees (Ln): } \\
\hline Total & 3.14 \\
\hline Less than $25 \%$ female presentation & 3.67 \\
\hline More than $25 \%$ female presentation & 2.98 \\
\hline More than $60 \%$ single race presentation & 4.18 \\
\hline Less than $60 \%$ single race presentation & 3.22 \\
\hline Category A employees & 3.78 \\
\hline Category B employees & 2.65 \\
\hline Age 35 years and less & 3.13 \\
\hline Age between $35-55$ years & 5.42 \\
\hline Age 55 years and older & 4.78 \\
\hline \multicolumn{2}{|c|}{ Average real sales turnover per employee (Ln): } \\
\hline Total & 3.24 \\
\hline Less than $25 \%$ female presentation & 3.05 \\
\hline More than $25 \%$ female presentation & 3.25 \\
\hline More than $60 \%$ single race presentation & 2.97 \\
\hline Less than $60 \%$ single race presentation & 3.26 \\
\hline Category A employees & 3.55 \\
\hline Category B employees & 3.09 \\
\hline Age 35 years and less & 2.54 \\
\hline Age between $35-55$ years & 2.03 \\
\hline Age 55 years and older & 3.76 \\
\hline Employee remuneration cost (Ln) & 0.26 \\
\hline Employee productivity (Ln) & 0.33 \\
\hline Capital/employee ratio (Ln) & 0.22 \\
\hline
\end{tabular}

Source: Author's analysis 